\title{
Achieving food security and high production of bioenergy crops through intercropping with efficient resource use in China
}

\author{
Yuanmei ZUO (凶), Zhenjiao ZHANG, Caihong LIU, Weina ZHANG \\ College of Resources and Environmental Sciences, China Agricultural University, Beijing 100193, China
}

\begin{abstract}
With high rates of food and nonrenewable fossil fuel consumption worldwide, we are facing great challenges in ensuring food and energy security to satisfy the world population. Intercropping, as an important and sustainable cropping practice in agroecosystems, has been widely practiced around the world. Many studies have shown that some plants can deliver high yields when intercropped with other plants. Here, we review the biological mechanisms in improving resource utilization efficiency and illustrate the practical application of intercropping in ensuring food and energy security through improving production. Identifying suitable energy plants for marginal land, land not suitable for food crops growth, is an effective strategy to acquire high production of bioenergy, thus removing competition between the use of land for food and energy. The effective application of intercropping provides a potential pathway for production of food crops and energy plants by improving resource use efficiency and resistance to environmental stress.
\end{abstract}

Keywords intercropping, food security, energy security, high production, marginal land

\section{Introduction}

Food insecurity and energy risks have seriously increased from the 21 st century and are likely to worsen with climate change and population growth ${ }^{[1]}$. Food and energy security are closely related to the survival and development of the world's population. Food and Agriculture Organization (FAO) statistics reveal that food supply satisfies overall demand, but regional shortages and food insecurity are

Received June 26, 2015; accepted August 10, 2015

Correspondence: zuoym@cau.edu.cn significant ${ }^{[2]}$. The rate of crop yield increase has slowed since the 1980s, and even stagnated in many areas ${ }^{[3]}$. In some countries, the rate of undernutrition is extremely high, which means there is chronic inadequacy of dietary energy supply. Meanwhile, environmental costs are imposed by agricultural production, including degradation of land, emission of green gases and pollution of fresh water. With the increasing global population, the future demand for grain production is huge, thus food security is facing huge challenges ${ }^{[4]}$. Food security is always the foundation of economic development, social stability and prosperity for a country, and it has become an urgent public concern, arguably inextricably entangled with social, political and environmental problems at many levels. Improving resource utilization efficiency and ecological protection should be urgently addressed for agricultural sustainable development in China with over 1.3 billion people and for such a large agricultural country to realize food security ${ }^{[5]}$.

Increased energy consumption follows a rapid surge in population growth. Global primary energy consumption will probably rise by $41 \%$ by $2035^{[6]}$. Among available energy, nonrenewable fossil energy, such as oil, fuel and gas consumption, accounts for about $90 \%$ of the world's total energy consumption. BP Statistical Review of World Energy statistics reveal that oil and gas reserves can only last 53.3 and 54.8 more years, respectively ${ }^{[7]}$. Fossil energy reserves will be exhausted one day, and many environment pollutants such as $\mathrm{SO}_{2}, \mathrm{CO}_{2}$, and suspended particulates derived from fossil energy combustion have serious effects on human health and threaten human survival and the environment ${ }^{[8]}$. Research on and adoption of renewable and environmentally sustainable energy needs to be given immediate priority. Bioenergy as renewable and clean energy has received great attention around the world and in recent years, many countries have developed policies and objectives for bioenergy. 
Biological resources, such as energy plants, which are the most direct and low-cost bioenergy raw materials, can now be used to produce heat, electricity, and fuel ${ }^{[9]}$. With limited cultivated land in China, the development of bioenergy must follow the principles of not using the grain intended for human consumption and not occupying the land intended for grain production ${ }^{[10]}$. Improving bioenergy production and ensuring food security should be synchronized. According to the statistics, there is approximately 260 million $\mathrm{hm}^{2}$ of wasteland in China ${ }^{[11]}$. Cultivation of energy plants on this land would effectively improve energy production, and also prevent water and soil erosion, and protect the environment, which is likely to be an important driver for other industries. The exploitation of marginal land to cultivate energy plants needs to be well reasoned, and other effective strategies should be tried to ensure sustainable development of bioenergy system in order to prevent bioenergy industry using food as raw materials; food which is needed for food security.

Intercropping, the mixed growth of two or more crop species simultaneously, is practiced on more than 28 million $\mathrm{hm}^{2}$ annually in China ${ }^{[12]}$, and has been widely practiced worldwide, such as Africa, India, Latin America and South-east Asia ${ }^{[13]}$. The advantages of numerous intercropping systems to enhance high productivity have been demonstrated ${ }^{[14]}$. Researchers have shown that intercropping yields can benefit from niche partitioning in which crop species utilize different soil (nutrient) and aboveground resources (light, water) spatially and temporally leading to higher resource utilization than when grown in monoculture ${ }^{[13,15]}$. The right combinations of crops can also reduce pests and disease attack, and help in controlling weeds ${ }^{[16]}$. So, this pattern applied in bioenergy production can probably improve the efficiency of marginal land use and enhance biomass production. A number of studies have shown that intercropping has great potential to contribute to food and energy security, as an efficient cropping system for sustainable agriculture economically and environmentally.

\section{Biological mechanisms of improved resource utilization in intercropping system}

\subsection{Intercropping improves acquisition of light, heat and water}

The right combination of crops could increase the efficiency of solar radiation use by extending light time and improving light capture for high yields ${ }^{[13,17]}$. C4 plants with high light saturation and $\mathrm{C} 3$ plants cultivated concurrently in the same field enhance the quality of light. Also, the $\mathrm{C} 3$ plants have high low energy light utilization, so as to improve light use efficiency. Intercropping with crops of different height, leaf type, plant type, can increase plant density and leaf area index, thus improving the amount of light interception ${ }^{[17]}$. The mean efficiency of radiation use of intercropped peanut was 79\% higher than that of peanut in monoculture. The combined radiation-use efficiency was more than twice that of peanut alone, but slightly lower than that of corresponding maize alone. The harvest index of intercropped peanut was about $13 \%$ lower than that of peanut alone, but monocultured peanut only produced $46 \%$ of the pods of peanut in intercropping system. These results indicated that maize/ peanut intercropping could help to increase yields through the efficient utilization of available light ${ }^{[18]}$. At the molecular level, photosynthesis-related proteins were both in higher abundance in the young leaves of intercropped peanut and maize compared to the plant in monocultures. Therefore, intercropping of maize and peanut can increase photosynthetic efficiency ${ }^{[19]}$.

Water is a critical factor in metabolism of plants and essential for achieving high yields. Water use efficiency is higher in intercropping compared to monoculture due to the spatial and temporal difference in the water requirements of the component crops ${ }^{[20]}$. Due to the different distribution of roots, component crops can take up water from different depths in soil ${ }^{[15]}$. Variation in plant density often affects water-utilization efficiency. This suggests that only the right combination of plants can achieve improved water utilization. Intercropped plants have increased ability to conserve water, largely because of high leaf area index and higher leaf area. Growth of maize and pea together lead to increased water uptake by pea ${ }^{[21]}$. Wheat/soybean intercropping increased water and radiation productivity in the south-east Pampas of Argentina ${ }^{[22]}$. The combined water use efficiency was $52 \%$ higher than for single crops in a maize/sunhemp intercropping system ${ }^{[23]}$.

\subsection{Intercropping improves acquisition of nutrients}

Intercropping is a cropping system delivering resource use efficiencies ${ }^{[3]}$. The mechanisms of achieving high-yield in intercropping systems are generally attributed to niche complementarity and positive interspecific interactions in resource use ${ }^{[24]}$. Research on rhizosphere processes and nutrient utilization in intercropping systems has provided a wealth of physiological evidence for interspecific facilitation between species ${ }^{[25]}$.

\subsubsection{Nitrogen}

The combined $\mathrm{N}$ uptake is higher in legume and nonlegume mixtures, which will improve nutrient status of crops. The mechanisms underlying $\mathrm{N}$ facilitation are probably as follows: (1) crops in an intercropping system acquire different $\mathrm{N}$ sources in order to grow well, (2) nonlegume crops take up $\mathrm{N}_{2}$ fixed by legume companion crop in different ways, such as direct root contact, root 
exudation and mycorrhizal association, and (3) the $\mathrm{N}$ fixing performance of the legume is improved, due to the non-legume competing for $\mathrm{N}$ from the soil and fertilizer. Farmers all over the world have known that legume/cereal intercropping increases the $\mathrm{N}$ nutrition of cereals leading to high yield of cereals, especially in unfertilized fields ${ }^{[26]}$. Wheat/soybean or maize/faba bean intercropping enhanced $\mathrm{N}$ acquisition significantly compared with monoculture ${ }^{[27,28]}$. Similar results with $\mathrm{N}$ uptake have also been found in barley/pea and sorghum/soybean intercropping ${ }^{[29,30]}$. $N$ derived from the atmosphere by faba bean when intercropped with maize increased by $8 \%-$ $33 \%$ at the start of flowering, $54 \%-61 \%$ at peak flowering, $18 \%-50 \%$ at the grain-filling stage, and up to $72 \%$ at maturity compared with faba bean alone. Based on experimental results, about $100 \mathrm{~kg} \cdot \mathrm{hm}^{-2}$ of $\mathrm{N}$ fertilizer can be saved in faba bean/maize intercropping ${ }^{[31]}$.

\subsubsection{Phosphorus}

Plants often perform poorly on soils with low concentrations of available P. Some of these soils contain a considerable amount of $\mathrm{P}$ that is unavailable to most species. $\mathrm{P}$ occurs in both organic and inorganic forms in soil, where organic P may account for 30\%-70\% of total $\mathrm{P}^{[32]}$. Plants cannot take up organic $\mathrm{P}$ directly, however, and organic $\mathrm{P}$ needs to be hydrolyzed by microbial or rootreleased phosphatases. Plants growing together often comprise species with and without P-mobilizing ability. P-mobilizing plants can facilitate non-P-mobilizing plants by mobilization of either organic or insoluble inorganic $\mathrm{P}$, through release of carboxylates, protons and enzymes from the roots. P-mobilizing plants release protons (in alkaline soil) and/or carboxylates (in any soil) into the rhizosphere to solubilize phosphates that are taken up by both the Pmobilizing plants and non-P-mobilizing plants in intercropping systems ${ }^{[33]}$. In P-impoverished soil, some species form dauciform roots or cluster roots ${ }^{[34]}$. Dauciform roots or cluster roots exude carboxylates and mobilize soluble $\mathrm{P}$ in soil. These plants enhance $\mathrm{P}$ acquisition for themselves and benefit their neighbors where $\mathrm{P}$ is limiting ${ }^{[35]}$. Numerous studies have shown facilitation of $\mathrm{P}$ utilization in the rhizosphere of intercropping systems. Lupin, pigeon pea and peanut are P-mobilizing crops and when intercropped with wheat, sorghum or maize, respectively, the $P$ acquisition improved significantly ${ }^{[24,36]}$. Chickpea, a species that releases acid phosphatases from roots into the rhizosphere to hydrolyze organic $\mathrm{P}$ into inorganic $\mathrm{P}$, facilitating $\mathrm{P}$ acquisition by associated non-mobilizing wheat and maize ${ }^{[37]}$. Faba bean can release protons, malate and citrate into the rhizosphere, thus mobilizing insoluble soil $\mathrm{P}$ to enhance $\mathrm{P}$ acquisition by the associated maize. Some intercropping systems can reduce fertilizer $\mathrm{P}$ requirements by efficient use soluble $\mathrm{P}$ in soil. Fertilizer $\mathrm{P}$ can be reduced by at least two thirds in faba bean/maize intercropping compared to that in wheat/maize intercropping $^{[24]}$.

\subsubsection{Micronutrients}

The World Health Organization reports that the lack of micronutrients such as iron and zinc represents a major threat to the health and development of populations around the world ${ }^{[38]}$. Enriching the nutrient content of crops as they grow provides a sustainable solution to malnutrition. In addition to mineral fertilization, standard breeding and transgenic approaches, intercropping has received increasing attention as a way to improve nutrient status of crops $^{[39]}$. However, relatively little research has been undertaken on the effects of intercropping on micronutrient status of crops. Some studies indicate intercropping between dicots and graminaceous species, which are strategy I and strategy II plants, respectively, would be the key to $\mathrm{Fe}$ and $\mathrm{Zn}$ biofortification ${ }^{[40]}$. In strategy I, an acidification/reduction mechanism, based on the secretion of protons into the rhizosphere, and the reduction of $\mathrm{Fe}(\mathrm{III})$ to $\mathrm{Fe}$ (II) by root ferric chelate reductase is used to enhance Fe solubility prior to uptake. The response of strategy II species include the biosynthesis and secretion of phytosiderophores which are chelators with a high affinity for $\mathrm{Fe}(\mathrm{III})$. Because of the secretion of these compounds, Strategy II species are more effective at mobilizing precipitated $\mathrm{Fe}$ and less affected by high $\mathrm{pH}$ and bicarbonate levels. Therefore, their tolerance to Fe stress in calcareous soils is higher than that of Strategy I plants ${ }^{[41]}$. Recently, several researchers have reported that graminaceous species improve Fe nutrition in Strategy I or low-phytosiderophore-secreting plants when they are cultured together, as well as enhancing $\mathrm{Zn}$ uptake ${ }^{[42]}$. Peanut/maize intercropping is a successful crop management strategy that results in more effective and sustainable practice for farmers due to improvement in Fe content of the peanut plants. When peanut and maize are grown together, the secretion of phytosiderophores from maize, as Strategy II plant, resulted in the efficient uptake of Fe(III)phytosiderophore complexes from the rhizosphere by peanut ${ }^{[43]}$. Peanut/maize intercropping not only improved the Fe status of peanuts, but also improved the shoot concentrations of other nutrients, including $\mathrm{K}, \mathrm{P}$ and $\mathrm{Zn}$. Moreover, the concentration of $\mathrm{Fe}$ and $\mathrm{Zn}$ in peanut seeds increased greatly in intercropping systems ${ }^{[44]}$. Also, improvement of $\mathrm{Fe}$ and $\mathrm{Zn}$ uptake in chickpea/wheat intercropping through interspecific root interactions has been reported ${ }^{[45]}$.

\subsection{Intercropping reduces the impact of pests, disease and weeds}

Intercropping has also been used as an efficient technology to reduce the impact of pests, disease and weeds. 
Compared with monoculture, intercropping improves the ability of crops to suppress pests, disease and weeds effectively, allowing significant reduction in pesticide use. Intercropping is seen as a more economically and environmentally sustainable strategy for the development of agriculture ${ }^{[44]}$.

Some researches have shown the biodiversity of ecosystem effects on phytophagous insect behavior, including host location, mating, movement, oviposition and feeding. There are probably two strategies in intercropping systems to control insect pests. Some plants can release volatile compounds that affect the ability of insects to locate hosts thereby reducing insect damage. The germination rate of sugarcane intercropped with garlic was higher and termite infestation rates significantly lower than in sugarcane monoculture because of volatiles from garlic repelled the termites ${ }^{[46]}$. Tobacco plants near clipped sagebrush had greatly reduced leaf damage from grasshoppers and cutworms during three field seasons compared to unclipped controls ${ }^{[47]}$. Some other plants can trap pests in order to protect the host crops. When sesame is intercropped with cotton, sesame with a higher rate of parasitic natural enemies can attract bollworm away from the cotton ${ }^{[48]}$. The damage to the kales caused by Lygus rugulipennis decreased when they were intercropped with alfalfa because it attracts L. rugulipennis ${ }^{[49]}$.

Crop disease is also a major limiting factor in agroecosystems. The total yield loss caused by crop disease is estimated at $10 \%$ for the whole world ${ }^{[50]}$. Crop heterogeneity is a possible solution to the vulnerability of monocultured crops to disease. Intercropping pattern can reduce disease severity in experimental plots and in the field. The fungus that causes blast disease in rice, which spreads through multiple cycles of asexual conidiospore production during the cropping seasons, cause necrotic spots on leaves and necrosis of panicles ${ }^{[51]}$. Disease susceptible and resistant rice cultivars planted together had 89\% greater yield and $94 \%$ less blast compared to single cultivar monoculture ${ }^{[52]}$. Garlic/rape intercropping reduced white rot in garlic ${ }^{[53]}$. A container-grown watermelon/rice combination relieved the occurrence of watermelon fusarium wilt which is the major obstacle to continuous cropping of watermelon ${ }^{[54]}$.

The loss of yield resulting from weeds accounts for $10 \%$ of the yield potential, and if not regulated the yield loss can reach 46\%-96\% ${ }^{[55]}$. Physical and chemical methods have been used by farmers around the world to control weeds competing with crops for light, water and nutrients. Physical methods are labor intensive and chemical methods can pollute the environment, harming human and animal health and limiting sustainable development of agriculture. Secondary metabolites produced by one kind of plant can inhibit the growth of another kind of plant. Taking advantage of this phenomenon can effectively suppress weeds in intercropping systems. Wheat intercropped with chickpea, not only increased land use efficiency, also significantly reduced the density and biomass of weeds in the field ${ }^{[56]}$. Banana intercropped with soybean or maize increased the yield of soybean and maize and controlled weeds, thus reducing the use of herbicides ${ }^{[57]}$.

Intercropping promotes stability and productivity. These positive biodiversity effects on stability and productivity arise from complementarity between species in above and below ground interactions in both natural and agricultural systems (Fig. 1). The above and below ground interactions can be exploited to improve plant growth and nutrition, with benefits from mutualists and defense against
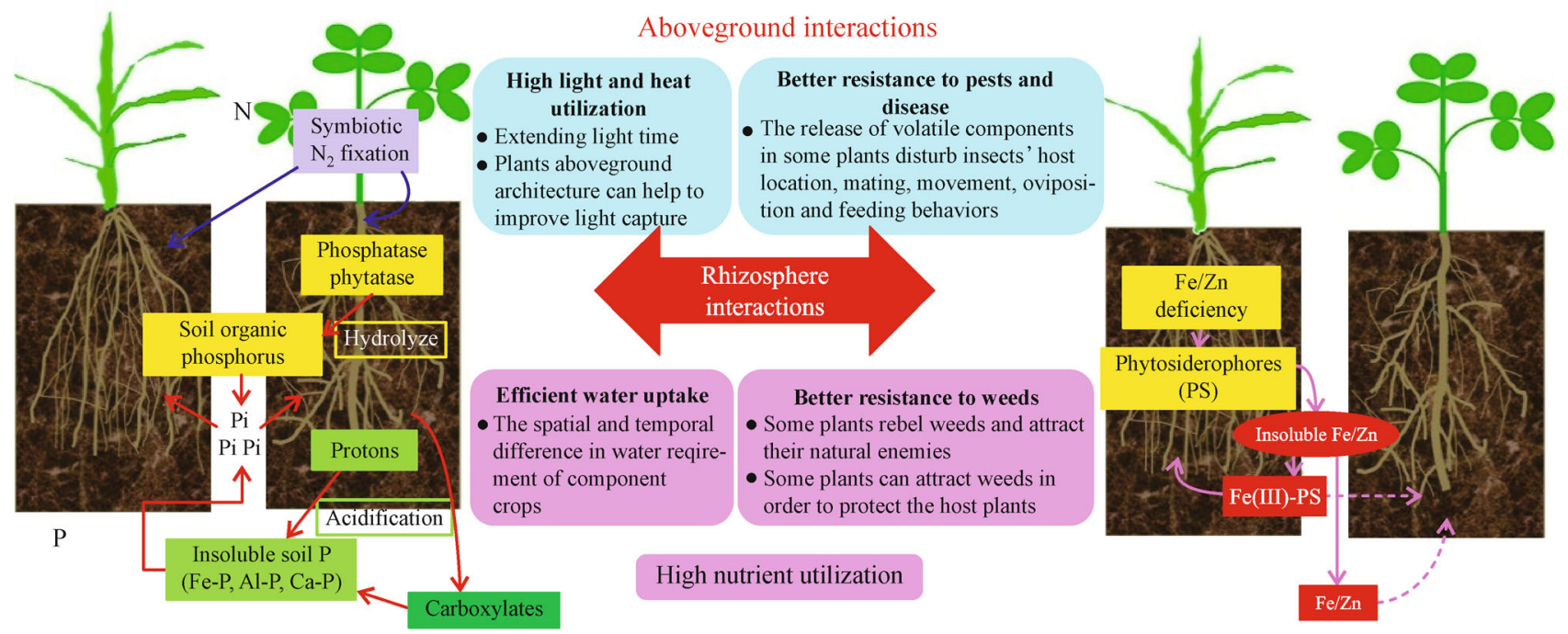

Fig. 1 Biological mechanisms of improving resource use efficiency in intercropping system 
antagonists. The ways in which these can influence food security and bioenergy plant production strategies are described below.

\section{Benefits of intercropping for food security}

3.1 Beneficial effects of intercropping on food security through improving nutrient resource use efficiency

Global agriculture faces considerable challenges and risks to ensure food security by increasing yields while reducing environment impacts ${ }^{[2,4]}$. Developing countries, including China, Ethiopia, India, Indonesia, Mali and Niger have paid considerable attention to enhancing productivity through intercropping ${ }^{[58]}$. There are very close relationships between yield advantage and nutrient uptake in intercropping systems. Exploiting beneficial above and below ground interactions could improve nutrient uptake, and form a part of a sustainable and long-term strategy to aid in improvement of crop yields (Table 1). There are a number of intercropping systems in north-west China including maize/faba bean, maize/potato, maize/vegetable, wheat/maize, wheat/soybean, wheat/sunflower, wheat/ vegetable systems ${ }^{[27,28,59,63]}$. $\mathrm{N}$ acquisition of faba bean significantly increased when intercropped with maize and the increase in grain yields of faba bean and maize were $21 \%-23 \%$ and $6.5 \%-11.8 \%$ of that in monoculture, respectively ${ }^{[60]}$. In a wheat/maize intercropping system, the yield of wheat was about $48 \%-56 \%$ higher compared to wheat alone. The growth of maize was suppressed during the growth stage of the wheat. However, after wheat was harvested, the maize recovered from the earlier suppression from the wheat and yield was higher than or similar to maize alone ${ }^{[28]}$. The yield of maize intercropped with bean increased by $26 \%{ }^{[59]}$. The concentration of iron in wheat grain and the concentration of iron and zinc in chickpea seeds both increased when they were grown together in the same field experiment. Intercropping could relieve potential $\mathrm{Fe}$ and $\mathrm{Zn}$ nutrient deficiency, particularly in harvested seeds ${ }^{[61]}$. Adopting such cropping systems with a more efficient use of soil nutrients and less reliance on chemical fertilizers is one promising way to develop sustainable crop production while maintaining high yields ${ }^{[63,64]}$. It is suggested that intercropping is a vital strategy for sustainable agriculture with high yields, high efficiency of nutrient use and environmental benefits ${ }^{[65]}$.

\subsection{Benefits of food security through mutualism in intercropping systems}

Beneficial interactions between crop species and mutualists allow improved yield and reduction of both biotic and abiotic above and below ground stresses and hold the potential to ensure productive and stable agroecosystems. Africa faces serious risks in feeding its population, and has reverted from being a net exporter of agricultural commodities to being a net importer over the last three decades. The amount imported is increasing at an almost exponential level ${ }^{[66]}$. With the increase of human population, average growth in food production in the continent has at best stagnated, and even declined over the last few decades in several places within the continent ${ }^{[67]}$. More than 500 million people will face food security risks by $2020^{[1]}$. One of the main reasons of the chronic food insecurity in Africa is poor crop yields, largely caused by insect pests, weeds and degraded soils. Smallholder cereal yield is severely constrained by insect pests and parasitic weeds in the genus Striga (Orobanchaceae) ${ }^{[68]}$. The yield loss damage caused by the larval stages of stem borers can be up to $88 \%{ }^{[69]}$. Push-pull technology, based on locally available companion plants, effectively addresses these constraints so as to increase grain yield. It involves intercropping cereal crops with a forage legume, Desmodium, and planting Napier grass as a border crop. Desmodium repels stemborer moths (push) and attracts their natural enemies, while Napier grass attracts them (pull). Desmodium is very effective in suppressing Striga while improving soil fertility through nitrogen fixation and improved organic matter content. Studies have shown that

Table 1 Evidence of high yield acquisition through improving nutrient uptake and reduce pests and weeds

\begin{tabular}{|c|c|c|}
\hline Resource utilization & Type of evidence & Reference \\
\hline \multirow[t]{4}{*}{ High nutrient acquisition } & The yield of wheat was about $48 \%-56 \%$ higher compared to the sole wheat in wheat/maize intercropping system & [28] \\
\hline & The yield of maize intercropped with bean increased by $26 \%$ & [59] \\
\hline & $\begin{array}{c}\text { The increase of grain yields of faba bean and maize were } 21 \%-23 \% \text { and } 6.5 \%-11.8 \% \text { of that in monoculture } \\
\text { respectively }\end{array}$ & [60] \\
\hline & $\begin{array}{c}\text { The concentration of iron in wheat seeds and the concentration of iron and zinc in chickpea seeds both increased when } \\
\text { they grew in the same field experiment simultaneously }\end{array}$ & [61] \\
\hline Resistance to disease & $\begin{array}{l}\text { Disease-susceptible rice varieties and resistant varieties planted together had } 89 \% \text { greater yield and blast was } 94 \% \text { less } \\
\text { severe than when they were grown in monoculture }\end{array}$ & [52] \\
\hline \multirow[t]{2}{*}{ Reduce weeds and pests } & Banana intercropping with soybean or maize can increase yield of soybean and maize and control weeds & [57] \\
\hline & $\begin{array}{c}\text { Control of striga and cereal stemborers resulting in significant increases in grain yields such as maize, sorghum and } \\
\text { finger millet }\end{array}$ & [62] \\
\hline
\end{tabular}


using push-pull technology provides effective control of stemborers and Striga, resulting in significant grain yield increases ${ }^{[62]}$. Both companion plants provide high-value animal fodder, facilitating milk production and diversifying farm income ${ }^{[70]}$.

Over 55000 smallholder farmers in East Africa have used this push-pull technology ${ }^{[16]}$. Adoption of this technology can suppress pests and control weeds effectively with low-cost, as well as improve soil fertility and prevent soil erosion. Farmers can benefit from this technology, and it is an effective way of exploiting intercropping for sustainable development of agriculture.

\section{Production of energy plants by intercropping}

Fast economic development has resulted in a significant increase in energy demand in China during the 21st century. Exploiting renewable bioenergy is one of the most effective measures for solving the energy shortage. Energy plants are the main source of biomass energy. As China cannot afford biomass energy production from its croplands, marginal lands will be important for biomass energy production $^{[71]}$. In recent years, China has given greater priority to energy plants and to identifying marginal land suitable for energy plant production.

\subsection{Benefits of energy plant production in marginal lands in China}

The total area of marginal lands suitable for energy plants in China is about 114 million $\mathrm{hm}^{2}$, and these lands are mainly found in Inner Mongolia, Sichuan, and Yunnan ${ }^{[10]}$. In Inner Mongolia and western regions, water resource deficiency is one of the main limiting factors for high crop yields. Large-scale drip irrigation technology has been adopted since the 1990s, and a set of mature technologies involving efficient utilization of water resources have been established in this region. Irrigation uses $95 \%$ of the water resource potential of Xinjiang Province ${ }^{[72]}$. The water suitable for crop growth is quite limited, but there is an abundance of poor quality water, with a preliminary estimate of 8.82 billion $\mathrm{m}^{3}$. Plants with high drought and salt tolerance can be irrigated with poor quality water to achieve high biomass, while the common crop plants cannot grow well with this poor quality water. The salt in soil with good permeability can be easily washed off to avoid affecting the growth of plants from excessive salt accumulation $^{[73]}$. Thus, the north-west arid regions have evident advantages for high production of resistant bioenergy plants.

There are many plant species in China, more than 4000 of which show high resistance to salt, drought and/or low temperature, and that have been identified as having potential as energy plants $^{[74]}$. Of these, Barbados nut (Jatropha curcas), Chinese silvergrass (Miscanthus sinensis), Jerusalem artichoke (Helianthus tuberosus), and sweet sorghum (Sorghum bicolor) are the main energy plants in China ${ }^{[75]}$. Jerusalem artichoke has high tolerance to drought, diseases and insect pests, and can survive at between $-40^{\circ} \mathrm{C}$ and $-30^{\circ} \mathrm{C}$. In the west region of Heilongjiang Province, Jerusalem artichoke can have a tuber yield of $30-45 \mathrm{t} \cdot \mathrm{hm}^{-2}$, even up to $75-150 \mathrm{t} \cdot \mathrm{hm}^{-2}$. Sweet sorghum can grow in different regions from the north to the south of China and can produce $4-6 \mathrm{t} \cdot \mathrm{hm}^{-2}$ of ethanol ${ }^{[76]}$. Caragana korshinskii and Xanthoceras sorbifolia are widely distributed in north-west regions. They have been used successfully used to produce biodiesel and organic acid. Bioenergy can replace fossil energy to reduce greenhouse gas emissions. If more energy plants were grown in marginal land in China, this would contribute to promoting the diversification of energy structure and ensuring energy security. Increasing the amount of clean energy ratio can reduce pollution by the energy industry, improving the environment and increasing biodiversity by high vegetation coverage, as well as reducing soil erosion, which together can deliver coordinated development of energy and environmental protection. The development of the biomass energy industry at a large-scale can also provide employment for the rural workforce and therefore contribute to the improvement of the rural economy ${ }^{[70]}$.

\subsection{Achieving high yield of high tolerance energy plants} through intercropping

There has been limited research on how to improve energy plant production. Energy plants are often planted as a single species, which can cause serious ecological imbalance and loss of biodiversity. Different energy plants, or energy plant-crop combinations can be grown together. Using intercropping to improve the output of biomass resources and land output is technically feasible. Firstly, intercropping can improve resource use efficiency and tolerance to environment stress in order to achieve high yields ${ }^{[13,16]}$. Secondly, intercropping can help to prevent water and soil loss in marginal lands and protect the environment. Ideally, high biomass and high energyyielding plants should be planted, and less efficient plants eliminated to increase the productivity of the energy plant system. Use of intercropping is suitable for China, which cannot only avoid using the grain intended for human consumption and occupying the land intended for grain production, but also form an eco-friendly, low-cost new planting system, which can restore the ecological balance in the environment. Achieving these economic and ecological benefits will also increase farm incomes and promote sustainable and stable development of both agricultural and biomass energy production.

Well considered plant combinations are an important 
way to insure the productivity of intercropping systems. Cassava is mainly grown in the north of China. Some researchers have shown the yield of cassava could be increased when intercropped with peanut or soybean and this system can improve soil nutrient utilization ${ }^{[77]}$. Preliminary studies have reported that some highly efficient energy plants are suitable for production in the western region of China, such as Haloxylon, Salix and $C$. korshinskii ${ }^{75]}$. It is worth noting that halophytes with high biomass are likely to have potential as energy plants that can grow well on large areas of saline soil in Xinjiang. Legume forages that grow in barren soil, including alfalfa, sweet clover and Sophora alopecuroides, with strong biological nitrogen fixation ability, can supply their own demand for nitrogen for growth and also benefit their neighbors. Legume forages and energy plants intercropping could promote the productivity of energy plants, while reducing nitrogen fertilizer inputs. Taking advantage of above and below ground interactions between legume forages and energy plants, and promoting energy plants and economic crop production has important theoretical and practical significance. Apricot/C. korshinskii intercropping is also common in Inner Mongolia. The right combinations of local plants, such as intercropping arrow tongue peas with $C$. korshinskii or switchgrass, $S$. alopecuroides intercropping with Haloxylon or Cistanche, can improve the land output and bring economic benefits. So intercropping also has wide development prospects for semi-arid areas and can contribute to ensuring energy security.

\section{Conclusions}

This review highlights the biological mechanisms involved in intercropping that improve natural resource utilization efficiency and control crop disease, pests and weeds to achieve higher crop production, and illustrates the practical application of intercropping in food and energy production. Faced with a serious food and energy crisis, the effective application of intercropping technology provides a potential pathway for cereal crop and energy plant production by improving light, heat, water and nutrient resources use efficiency and tolerance to environmental stress. It is suggested that fine-tuning cropping patterns at different scales from individual to ecosystem level will be an economically and environmentally sustainable way for ensuring food and energy security.

However, intercropping is not always beneficial and does not always increase yields ${ }^{[78]}$. So the right combination of plants is critical for successful intercropping. Researchers should further utilize the genetic characteristics and physiological traits of appropriate plants to help farmers to select productive combinations.

Internationally, researchers have begun to pay attention to energy plants inform the 1950s. Although the study of energy plants in China has come later than some other countries, China has, with many energy plant species and large areas of marginal land, good prospects for developing bioenergy production. Cultivation of energy plants in marginal land cannot only provide energy resources, but can also improve the land output and bring economic benefits, while preventing soil erosion, wind erosion and desertification (Fig. 2). However, at present, energy plants production on a large scale face difficulties in the mechanization of planting, harvesting and processing, so appropriate equipment needs to be developed for bioenergy production. In addition, more attention needs to be given to how to efficiently produce clean bioenergy from energy plants and at low cost.

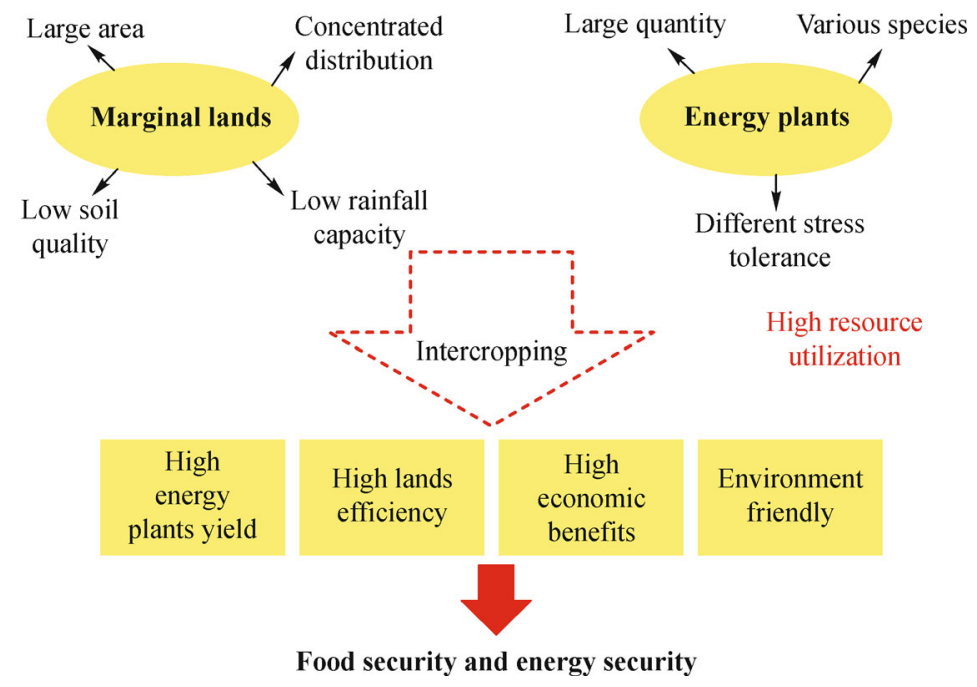

Fig. 2 Model chart of improving energy plant production through intercropping in marginal land to ensure food and energy security 
Acknowledgements The authors would like to thank National Sciencetechnology Support Plan Projects of China (2013BAD22B02) for financial support.

Compliance with ethics guidelines Yuanmei Zuo, Zhenjiao Zhang, Caihong Liu, and Weina Zhang declare that they have no conflict of interest or financial conflicts to disclose.

This article does not contain any studies with human or animal subjects performed by any of the authors.

\section{References}

1. FAO. The status of food insecurity in the world. Food and Agriculture Organization, 2013

2. Foley J A, Ramankutty N, Brauman K A, Cassidy E S, Gerber J S, Johnston M, Mueller N D, O'Connell C, Ray D K, West P C, Balzer C, Bennett E M, Carpenter S R, Hill J, Monfreda C, Polasky S, Rockström J, Sheehan J, Siebert S, Tilman D, Zaks D P M. Solutions for a cultivated planet. Nature, 2011, 478(7369): 337-342

3. Grassini P, Eskridge K M, Cassman K G. Distinguishing between yield advances and yield plateaus in historical crop production trends. Nature Communications, 2013, 4: 2918

4. Tilman D, Balzer C, Hill J, Befort B L. Global food demand and the sustainable intensification of agriculture. Proceedings of the National Academy of Sciences of the United States of America, 2011, 108(50): 20260-20264

5. Zhang F, Chen X, Vitousek P. Chinese agriculture: an experiment for the world. Nature, 2013, 497(7447): 33-35

6. Bob D. Energy outlook 2035. Available at bp Website on January 15, 2014

7. Christof R. Energy in 2013: taking stock. Available at bp Website on June 16, 2014

8. Gao C, Yin $\mathrm{H}$, Ai N, Huang Z. Historical analysis of $\mathrm{SO}_{2}$ pollution control policies in China. Environmental Management, 2009, 43(3): 447-457

9. Yuan J S, Tiller K H, Al-Ahmad H, Stewart N R, Stewart C N Jr. Plants to power: bioenergy to fuel the future. Trends in Plant Science, 2008, 13(8): 421-429

10. Jiang D, Hao M, Fu J, Zhuang D, Huang Y. Spatial-temporal variation of marginal land suitable for energy plants from 1990 to 2010 in China. Scientific Reports, 2014, 4: 5816

11. Ministry of Land and Resources of the People's Republic of China (MLR). Comprehensive land use planning of 1997-2010. Available at MLR Website on January 15, 2014

12. Liu X. The farming systems. Beijing: China Agricultural University Press, 1994 (in Chinese)

13. Vandermeer J. The ecology of intercropping. Cambridge: Cambridge University Press, 1989

14. Li L, Yang S C, Li X L, Zhang F S, Christie P. Interspecific complementary and competitive interactions between intercropped maize and faba bean. Plant and Soil, 1999, 212(2): 105-114

15. Zhang F S, Shen J B, Zhang J L, Zuo Y M, Li L, Chen X P. Chapter one-rhizosphere processes and management for improving nutrient use efficiency and crop productivity: implications for China.

Advances in Agronomy, 2010, 107: 1-32
16. Khan Z R, Midega C A O, Pittchar J O, Murage A W, Birkett M A, Bruce T J A, Pickett J A. Achieving food security for one million sub-Saharan African poor through push-pull innovation by 2020 . Philosophical Transactions of the Royal Society of London. Series B, Biological Sciences, 2014, 369(1639): 20120284

17. Zhang L Z, Van der Werf W, Bastiaans L, Zhang S, Li B, Spiertz J H J. Light interception and utilization in relay intercrops of wheat and cotton. Field Crops Research, 2008, 107(1): 29-42

18. Awal M A, Koshi H, Ikeda T. Radiation interception and use by maize/peanut intercrop canopy. Agricultural and Forest Meteorology, 2006, 139(1): 74-83

19. Xiong H, Shen H, Zhang L, Zhang Y, Guo X, Wang P, Duan P, Ji C, Zhong L, Zhang F, Zuo Y. Comparative proteomic analysis for assessment of the ecological significance of maize and peanut intercropping. Journal of Proteomics, 2013, 78: 447-460

20. Sanchez P A. Properties and management of soils in the tropics. Soil Science, 1977, 124(3): 187

21. Ogindo $\mathrm{H} \mathrm{O}$, Walker S. Comparison of measured changes in seasonal soil water content by rainfed maize-bean intercrop and component cropping systems in a semi-arid region of southern Africa. Physics and Chemistry of the Earth Parts $A / B / C, 2005,30$ (11): 799-808

22. Caviglia O P, Sadras V O, Andrade F H. Intensification of agriculture in the south-eastern Pampas: I. Capture and efficiency in the use of water and radiation in double-cropped wheat-soybean. Field Crops Research, 2004, 87(2): 117-129

23. Nsongela S. Water use efficiency and economic effects of a maizelegume intercropping system. Dissertation for the Master Degree. Lusaka: University of ZAMBIA, 1999

24. Li L, Li S M, Sun J H, Zhou L L, Bao X G, Zhang H G, Zhang F S. Diversity enhances agricultural productivity via rhizosphere phosphorus facilitation on phosphorus-deficient soils. Proceedings of the National Academy of Sciences of the United States of America, 2007, 104(27): 11192-11196

25. Zuo Y M, Zhang F S, Li X L, Cao Y P. Studies on the improvement in iron nutrition of peanut by intercropping with maize on a calcareous soil. Plant and Soil, 2000, 220(1-2): 13-25

26. Hauggaard-Nielsen H, Jensen E S. Facilitative root interactions in intercrops. Plant and Soil, 2005, 274(1-2): 237-250

27. Li L, Sun J H, Zhang F S, Li X L, Rengel Z, Yang S C. Wheat/maize or wheat/soybean strip intercropping: II. Recovery or compensation of maize and soybean after wheat harvesting. Field Crops Research, 2001, 71(3): 173-181

28. Li L, Sun J H, Zhang F, Yang S C, Rengel Z. Wheat/maize or wheat/ soybean strip intercropping: I. Yield advantage and interspecific interactions on nutrients. Field Crops Research, 2001, 71(2): 123137

29. Izaurralde R C, McGill W B, Juma N G. Nitrogen fixation efficiency, interspecies $\mathrm{N}$ transfer, and root growth in barley-field pea intercrop on a Black Chernozemic soil. Biology and Fertility of Soils, 1992, 13(1): 11-16

30. Fujita K, Ogata S, Matsumoto K, Masuda T, Ofosu-Budu G K, Kazue K. Nitrogen transfer and dry matter production in soybean and sorghum mixed cropping system at different population densities. Soil Science and Plant Nutrition, 1990, 36(2): 233241 
31. Li Y Y, Yu C B, Cheng X, Li C J, Sun J H, Zhang F S, Lambers H, Li L. Intercropping alleviates the inhibitory effect of $\mathrm{N}$ fertilization on nodulation and symbiotic $\mathrm{N}_{2}$ fixation of faba bean. Plant and Soil, 2009, 323(1-2): 295-308

32. Dalal R. Organic phosphorus. Advances in Agronomy, 1977, 29: 83117

33. Li L, Tilman D, Lambers H, Zhang F S. Plant diversity and overyielding: insights from belowground facilitation of intercropping in agriculture. New Phytologist, 2014, 203(1): 63-69

34. Lambers H, Chapin F S III, Pons T L. Plant physiological ecology, 2nd ed. New York: Springer, 2008, 255-3320

35. Shane M W, Cawthray G R, Cramer M D, Kuo J, Lambers H. Specialized 'dauciform' roots of Cyperaceae are structurally distinct, but functionally analogous with 'cluster' roots. Plant, Cell \& Environment, 2006, 29(10): 1989-1999

36. Ae N, Arihara J, Okada K, Yoshihara T, Johansen C. Phosphorus uptake by pigeon pea and its role in cropping systems of the Indian subcontinent. Science, 1990, 248(4954): 477-480

37. Li L, Tang C X, Rengel Z, Zhang F S. Chickpea facilitates phosphorus uptake by intercropped wheat from an organic phosphorus source. Plant and Soil, 2003, 248(1-2): 297-303

38. World Health Organization (WHO). Micronutrient deficiency: iron defi-ciency anaemia. Available at WHO Website on December 30, 2007

39. Zhu C, Naqvi S, Gomez-Galera S, Pelacho A M, Capell T, Christou P. Transgenic strategies for the nutritional enhancement of plants. Trends in Plant Science, 2007, 12(12): 548-555

40. Zuo Y M, Zhang F S. Iron and zinc biofortification strategies in dicot plants by intercropping with gramineous species: a review. Agronomy for Sustainable Development, 2009, 29(1): 63-71

41. Ma J F. Plant root responses to three abundant soil minerals: silicon, aluminum and iron. Critical Reviews in Plant Sciences, 2005, 24(4): 267-281

42. Zhang F S, Treeby M, Römheld V, Marschner H. Mobilization of iron by phytosiderophores as affected by other micronutrients. Berlin: Springer Netherlands, 1991, 205-210

43. Xiong H, Kakei Y, Kobayashi T, Guo X, Nakazono M, Takahashi H, Nakanishi H, Shen H, Zhang F, Nishizawa N K, Zuo Y. Molecular evidence for phytosiderophore-induced improvement of iron nutrition of peanut intercropped with maize in calcareous soil. Plant, Cell \& Environment, 2013, 36(10): 1888-1902

44. LaMondia J A, Elmer W H, Mervosh T L, Cowles R S. Integrated management of strawberry pests by rotation and intercropping. Crop Protection, 2002, 21(9): 837-846

45. Gunes A, Inal A, Adak M S, Alpaslan M, Bagci E G, Erol T, Pilbeam D J. Mineral nutrition of wheat, chickpea and lentil as affected by mixed cropping and soil moisture. Nutrient Cycling in Agroecosystems, 2007, 78(1): 83-96

46. Ahmed S, Khan R R, Hussain G, Riza M A, Hussain A. Effect of intercropping and organic matter on the subterranean termites population in sugarcane field. International Journal of Agriculture and Biology, 2008, 10(5): 581-584

47. Karban R, Baldwin I T, Baxter K J, Laue G, Felton G W. Communication between plants: induced resistance in wild tobacco plants following clipping of neighboring sagebrush. Oecologia, 2000, 125(1): 66-71
48. Andow D A. Vegetational diversity and arthropod population response. Annual Review of Entomology, 1991, 36(1): 561-586

49. Accinelli G, Lanzoni A, Ramilli F, Dradi D, Burgiol G. Trap crop: an agroecological approach to the management of Lygus rugulipennis on lettuce. Bulletin of Insectology, 2005, 58(1): 9-14

50. Mundt C C. Use of multiline cultivars and cultivar mixtures for disease management. Annual Review of Phytopathology, 2002, 40 (1): $381-410$

51. Baker B, Zambryski P, Staskawicz B, Dinesh-Kumar S P. Signaling in plant-microbe interactions. Science, 1997, 276(5313): 726-733

52. Zhu Y, Chen H, Fan J, Wang Y, Li Y, Chen J, Fan J, Yang S, Hu L, Leung H, Mew T W, Teng P S, Wang Z, Mundt C C. Genetic diversity and disease control in rice. Nature, 2000, 406(6797): 718722

53. Zewde T, Fininsa C, Sakhuja P K, Ahmed S. Association of white $\operatorname{rot}$ (Sclerotium cepivorum) of garlic with environmental factors and cultural practices in the North Shewa highlands of Ethiopia. Crop Protection, 2007, 26(10): 1566-1573

54. Ren X L, Su S M, Yang X M, Xu Y C, Huang Q W, Shen Q R. Intercropping with aerobic rice suppressed Fusarium wilt in watermelon. Soil Biology \& Biochemistry, 2008, 40(3): 834-844

55. Kim K U. Trends and expectations for research and technology in the Asia - Pacific region. Weed Biology and Management, 2001, 1 (1): 20-24

56. Banik P, Midya A, Sarkar B K, Midya A, Ghose S S. Wheat and chickpea intercropping systems in an additive series experiment: advantages and weed smothering. European Journal of Agronomy, 2006, 24(4): 325-332

57. Anaya A L, Ortega R C, Rodríguez V N. Impact of allelopathy in the traditional management of agroecosystems in Mexico. Berlin: Springer Netherlands, 1992, 271-301

58. Diaz R J, Rosenberg R. Spreading dead zones and consequences for marine ecosystems. Science, 2008, 321(5891): 926-929

59. West T D, Griffith D R. Effect of strip-intercropping corn and soybean on yield and profit. Journal of Production Agriculture, 1992, 5(1): 107-110

60. Jeong J, Guerinot M L. Biofortified and bioavailable: the gold standard for plant-based diets. Proceedings of the National Academy of Sciences of the United States of America, 2008, 105(6): 17771778

61. Li L, Zhang L Z, Zhang F S. Crop mixtures and the mechanisms of overyielding. Encyclopedia of biodiversity, 2013, 2: 382-395

62. Whitney A S. Nitrogen fixation by three tropical forage legumes and the utilization of legume-fixed nitrogen by their associated grasses. Dissertation for the Doctoral Degree. Honolulu: University of Hawaii, 1966

63. Zhang F S, Shen J B. Progress in plant nutrition and rhizosphere research in "Research Progress in Plant Protection and Plant Nutrition" (China Agronomy Society, Ed.). Beijing: China Agriculture Press, 1999, 458-469

64. Zhang F S, Shen J B. The preliminary development of the theoretical concept of rhizosphere ecosystem and its research emphasis. Journal of Agriculture Science and Technology, 1999, 4: 15-20

65. Zhang F S, Shen J B, Li L, Liu X J. An overview of rhizosphere processes related with plant nutrition in major cropping systems in China. Plant and Soil, 2004, 260(1-2): 89-99 
66. Rakotoarisoa A M, Iafrate M, Paschali M. Why has Africa become a net food importer. Available at African Women (womin) Website on January 2, 2011

67. The World Bank. World development report 2008. Available at World Bank Website on December 30, 2008

68. Maes K. African cereal stem borers: economic importance, taxonomy, natural enemies and control, Wallingford: CABI, 1998, $87-98$

69. Kfir R, Overholt W A, Khan Z R, Polaszek A. Biology and management of economically important lepidopteran cereal stem borers in Africa. Annual Review of Entomology, 2002, 47(1): 701731

70. Khan Z R, Amudavi D M, Midega C A O, Hassanali A, Pickett J A. Farmers' perceptions of a 'push-pull' technology for control of cereal stemborers and Striga weed in western Kenya. Crop Protection, 2008, 27(6): 976-987

71. Tang Y, Xie J S, Geng S. Marginal land-based biomass energy production in China. Journal of Integrative Plant Biology, 2010, 52 (1): $112-121$
72. Jia Z L. The preliminary study of the technology in governing soil salinization in Xinjiang. Water-Saving Irrigation, 2011, 11: 50-52 (in Chinese)

73. Peng K S. An analysis of the western development and water resources protection. Water Conservancy Economy, 2002, 8: 227233 (in Chinese)

74. Lin C S, Li Y Y, Liu J L, Zhu W B, Cheng X. Diversity of energy plant resources and its prospects for the development and application. Henan Agricultural Sciences, 2006, 12: 17-23 (in Chinese)

75. Li X, Hou S, Su M, Yang M, Shen S, Jiang G, Qi D, Chen S, Liu G. Major energy plants and their potential for bioenergy development in China. Environmental Management, 2010, 46(4): 579-589

76. Shi Y C. Biomass: to win the future. Beijing: China Agricultural University Press, 2010 (in Chinese)

77. Chen X S. Introduction of cassava intercropping. Guangxi Tropic Agriculture, 2003, 3: 36-37 (in Chinese)

78. Letourneau D K, Armbrecht I, Rivera B S, Lerma J M, Carmona E J, Daza M C, Escobar S, Galindo V, Gutiérrez C, López S D, Mejía J L, Rangel A M A, Rangel J H, Rivera L, Saavedra C A, Torres A M, Trujillo A R. Does plant diversity benefit agroecosystems? A synthetic review. Ecological Applications, 2011, 21(1): 9-21 